慶應義塾大学学術情報リポジトリ

Keio Associated Repository of Academic resouces

\begin{tabular}{|c|l|}
\hline Title & Some effects of temperature on fluorescence for pure toluene and liquid scintillator \\
\hline Sub Title & \\
\hline Author & $\begin{array}{l}\text { 本間, 義夫(Honma, Yoshio) } \\
\text { 村瀬, 裕子( Murase, Yuko) } \\
\text { 石井, 通子( Ishii, Michiko) }\end{array}$ \\
\hline Publisher & 共立薬科大学 \\
\hline Publication year & 1985 \\
\hline Jtitle & $\begin{array}{l}\text { 共立薬科大学研究年報 (The annual report of the Kyoritsu College of } \\
\text { Pharmacy). No.30 (1985.) ,p.78- 79 }\end{array}$ \\
\hline JaLC DOI & \\
\hline Abstract & \\
\hline Notes & 抄録 \\
\hline Genre & Technical Report \\
\hline URL & https://koara.lib.keio.ac.jp/xoonips/modules/xoonips/detail.php?koara_id=AN00062898-0000003 \\
& 0-0078 \\
\hline
\end{tabular}

慶應義塾大学学術情報リポジトリ(KOARA)に掲載されているコンテンツの著作権は、それぞれの著作者、学会または出版社/発行者に帰属し、その権利は著作権法によって 保護されています。引用にあたっては、著作権法を遵守してご利用ください。

The copyrights of content available on the KeiO Associated Repository of Academic resources (KOARA) belong to the respective authors, academic societies, or publishers/issuers, and these rights are protected by the Japanese Copyright Act. When quoting the content, please follow the Japanese copyright act. 


\title{
Some Effects of Temperature on Fluorescence for Pure Toluene and Liquid Scintillator*
}

\author{
Yoshio Homma, Yuko Murase and Michiko IshiI \\ 本間義夫，村瀬裕子，石井通子
}

Temperature dependence of fluorescence spectra has been measured for the solutions of a number of compounds. It is commonly recognized that the relative fluorescence yields for some solute displaying self-quenching show a decrease with decreasing temperature at high concentrations. For example, this is very clearly shown by the fluorescence spectra of a highly concentrated 2,5-diphenyloxazole(PPO)solution in toluene as a function of temperature. It should be noted the observation was made for a highly concentrated PPO solution over a rather higher range of temperature. In the case of conversion electron and $\alpha$ - and $\beta$-particle excitation of a dilute PPO solution $(4 \mathrm{~g} / \mathrm{l})$ in toluene described in the preceding paper, however, we have found that the pulseheight distributions for these particles in the liquid scintillator increase markedly with decreasing temperature, and suggested that the temperature effect may be attributed to the increase of excimer fluorescence of toluene. Therefore, as a part of a continuing study of the temperature dependence of fluorescence spectra, it was decided to measure the fluorescence spectrum from pure toluene and a dilute PPO solution in toluene under ultra-violet and $\alpha$ - and $\beta$-particles excitation at lower temperatures.

Cooling pure toluene dramatically affects the emission spectrum. The peak of the fluorescence spectra shifts from the initial wavelength, i.e., the room temperature position $(302 \mathrm{~nm})$, toward longer wavelength with decreasing temperature. The fluorescence maximum of solution spectrum of toluene $(284 \mathrm{~nm})$, which assigned to the monomer emission of toluene, agrees satisfactorily with that reported previously. However, the fluorescence maximum of pure toluene at room temperature shifts to longer wavelength than that of the monomer spectrum. These red shift may be well explained on the assumption that the fluorescence spectrum of pure toluene includes a large excimer emission component especially at lower temperatures according to the concept postulated by Birks et al.

Another interesting observation is that the fluorescence intensity from PPO toluene solution $(4 \mathrm{~g} / \mathrm{l})$ also increases with decreasing temperature, although the fluorescence maxima remain unchanged.

The results shown in this study strongly suggests that the increase in fluorescence intensity of dilute PPO solution, at least in part, predominately due to the increase

* 本報告はJ. Radioanal. Nucl. Chem., Letters 95 (5), 281-290（1985）に発表 
in the excimer fluorescence of the solvent. That is, at lower temperatures the formation of solvent excimers would be promoted and the increase in energy transfer between solvent molecules, and hence, that in light output of the liquid scintillator occurs.

Some author reported that PPO solution do not exhibit an increase in response with a decrease in the temperature. However, it must be noted that not only the sample solution but also the photomultiplier tubes used were also cooled in the study, and that cooling the whole counting system can occasion misleading interpretation of the results. Moreover, the temperature range in the earlier studies was relatively limited $\left(-10\right.$ to $18^{\circ} \mathrm{C},-25$ to $\left.23^{\circ} \mathrm{C}\right)$ compared with that for present study.

The beta spectrum for ${ }^{210} \mathrm{~Pb},{ }^{210} \mathrm{Bi}$ and ${ }^{35} \mathrm{~S}$ also shifts to higher pulse-height with decreasing temperature. Therefore, even the very soft beta particles from these nuclides come to be counted so that the total counting rates of these nuclides increase.

The temperature effect observed cannot be attributed to the shift of the balancepoint and calibration curve for external standardization of liquid scintillation system as described in as earlier report, because the pulses from the sum circuit are directly fed through an amplifier to a 1024-channel pulse-height analyzer in this study.

In conclusion, it seems relatively certain from the preceding discussion that at lower temperatures the formation of solvent excimer would be promoted and that the increase in energy transfer between solvent molecules, and hence, in light output of liquid scintillator occurs, because the condition of excimer formation is the parallel orientation of two adjacent molecules. 